\title{
PCSK9 Gene
}

National Cancer Institute

\section{Source}

National Cancer Institute. PCSK9 Gene. NCI Thesaurus. Code C122915.

This gene is involved in both cholesterol metabolism and protein degradation. 